\title{
Profitability of Vegetables in Hill Agriculture: An Economic Analysis
}

\author{
Harshika Choudhary ${ }^{1}$, Deepshikha Bisht ${ }^{1}$, P.S. Badal ${ }^{1}$, Virendra Singh $^{3}$, \\ Ritu Shah $^{2 *}$ and Manohar Saryam ${ }^{2}$
}

${ }^{1}$ Department of Agricultural Economics, ${ }^{2}$ Department of Extension Education, Institute of Agricultural Sciences, Banaras Hindu University, Varanasi -221005, U.P., India

${ }^{3}$ Department of Agricultural Economics, College of Agriculture, Pantnagar-263145,

Uttarakhand, India

*Corresponding author

\begin{tabular}{|c|c|}
\hline & A B S T R A C T \\
\hline Keywords & \\
\hline $\begin{array}{l}\text { Hill agriculture, } \\
\text { Economics, Cost } \\
\text { and returns, } \\
\text { Vegetables, } \\
\text { Horticulture. }\end{array}$ & \multirow{3}{*}{$\begin{array}{l}\text { Though India has emerged as a major producer of horticultural crops and the share of } \\
\text { horticulture in the economy has been increasing, there is still a lot of scope in harnessing } \\
\text { the potential of this sector. Sectors like horticulture (both fruit and vegetable cultivation) } \\
\text { have a comparative advantage in the hilly region due to its agro-climatic conditions. The } \\
\text { study was conducted in Dhari block of Nainital district, Uttarakhand. Both primary and } \\
\text { secondary data was collected for the study purpose. Four vegetables covering maximum } \\
\text { area under vegetable cultivation was selected. On this basis, pea, cabbage, French bean and } \\
\text { tomato are selected for the study. The costs in and returns from each vegetable crop is } \\
\text { analysed and found that the returns per rupee invested from pea, cabbage, tomato, bean } \\
\text { were } 1.56,1.25,1.20 \text { and } 1.10 \text { respectively. Thus, it is profitable for vegetable growers to } \\
\text { adopt cultivation in the region. }\end{array}$} \\
\hline Article Info & \\
\hline $\begin{array}{l}\text { Accepted: } \\
\text { 17 June } 2017 \\
\text { Available Online: } \\
\text { 10 August } 2017\end{array}$ & \\
\hline
\end{tabular}

\section{Introduction}

India is endowed with a remarkably heterogeneous area characterized by a great diversity of agro climatic zones, allowing for production of a variety of horticultural crops such as fruits, vegetables, flowers, spices, plantation crops, root and tuber crops, and medicinal and aromatic crops. Horticulture exports have helped the country to earn Rs 14,000 crore in 2011-12. Horticulture accounts for $30 \%$ of India's agricultural GDP from $8.5 \%$ of the cropped area (Economic Survey, 2015-16).

Though India has emerged as a major producer of horticultural crops and the share of horticulture in the economy has been increasing, there is still a lot of scope in harnessing the potential of this sector. Fruits and vegetables account for nearly $90 \%$ of the total horticulture production in the country. India is now the second largest producer of fruits and vegetables in the world and is the leader in several horticultural crops, namely mango, banana, papaya, cashew nut, areca nut, potato, and okra (Horticultural Statistics at a Glance, 2015).

Uttarakhand is primarily a mountainous state with only about ten percent of its total geographical area in the plains. Further, with 
more than three-fourth (78 percent) of its total population dependent on agriculture for livelihood. Agriculture is an important sector in state's economy and contributes $15.5 \%$ in Gross State Domestic Product. The yield from the field crops is not very high in the hilly areas of the state. This is largely due to the mountainous terrain that makes it impossible to adopt mechanized modern agriculture in these areas. Thus, these crops are produced in the hills mostly to fulfill the subsistence needs of the farmers. Sectors like horticulture (both fruit and vegetable cultivation) have a comparative advantage in the region due to its agro-climatic conditions.

The various constraints faced by the vegetable growers are their poor resource base and the resources at the disposal of the farmers are allocated in accordance of the importance and suitability of enterprises on the farms. Productivity of vegetable crops is unable to reach its optimum level. Low productivity may be attributed to poor infrastructure, poor irrigation, small and fragmented land holdings, and low investment capacity of the farmers, fragile ecosystem and inaccessibility to technology. The perishable nature of the vegetables also results in inability on the part of producers to manage supply in assembling markets.

The current paper examines the cost in and returns from the four major producing vegetables in Uttarakhand.

\section{Materials and Methods}

The study was conducted in Dhari block of Nainital district. Both primary and secondary data was collected for the study purpose. Selection of vegetables: Four vegetables covering maximum area under vegetable cultivation was selected. On this basis, pea, cabbage, French bean and tomato are selected for the study. Around 60 farmers was selected from the 4 villages with the restriction that 15 farmers represent each vegetable. To estimate costs in and returns from vegetable production total costs and returns were calculated using CACP cost concepts.

Returns from the vegetables were estimated by calculating gross returns and net returns.

$\mathrm{GR}_{\mathrm{j}}=\mathrm{MPj} \times \mathrm{MPP}_{\mathrm{j}}$

$\mathrm{NRj}^{*}=\mathrm{GRj}-\mathrm{COPj}^{*}$

Where,

$\mathrm{GR}_{\mathrm{j}}=$ Gross returns from $\mathrm{j}^{\text {th }}$ vegetable crop (Rs/ha)

$\mathrm{MP}_{\mathrm{j}}=$ Main products of $\mathrm{j}^{\text {th }}$ vegetable crop (Qt/ha)

$\mathrm{MPP}_{\mathrm{j}}=$ Price of main product of $\mathrm{j}^{\text {th }}$ vegetable crop (Rs/Qt)

$\mathrm{NRj}^{*}=$ Net returns from $\mathrm{j}^{\text {th }}$ vegetable crop (Rs/ha)

$\mathrm{COPj}^{*}=$ Cost of production of $\mathrm{j}^{\text {th }}$ vegetable crop (Rs/ha)

$\mathrm{j}=$ Vegetable crop to be selected.

( ${ }^{*}$ denotes net returns over different cost concept i.e. $\operatorname{Cost} \mathrm{A}_{1}, \operatorname{Cost}_{1} \ldots \ldots \operatorname{CostC}_{3}$ )

\section{Results and Discussion}

The profitability of a crop depends on the level of costs and returns. The right use of inputs is necessary to maximize the level of output in any production enterprise. Hence, study of costs and returns in various crop enterprises exercises an important role in determining the relative profitability of various crop enterprises. Tables 1 to 2 reveal the costs and returns in the cultivation of pea, cabbage, tomato and bean.

\section{Costs and returns in pea cultivation (Rs/ha)}

Costs of production of pea are detailed in table 1. The total cost of production i.e., cost C3 was Rs. 72060.39 per ha. It is evident 
from table that the cost $\mathrm{A} 1$, i.e., the direct cost involved in pea production, was Rs. 29154.90 per ha. The operational cost (Rs. 23004.53 per ha) constituted around 31.92 per cent to the total cost (Cost C3). Cost incurred on input materials was observed to be Rs. 19696.38 per ha with 27.33 per cent of the total cost (Cost C3) of production. The other costs accounted for 31.65 per cent of the total cost (Cost C3). A perusal of the table further reveals that human labour (family and hired), rental value and seed were the important items of cost in the area.

Returns from pea production are also shown in table 1. It could be seen from the table, that the average pea yield was found to be 106.97 quintals per ha. The gross income was figured as Rs. 112649.50 per ha. The net return per ha over total cost i.e., cost C3 was found to be Rs. 40589.54 per ha. The net return over direct cost i.e., cost A1 was found to be Rs. 83495.04 per ha. The ratio of gross return to the cost C3 was calculated as 1.56 indicating that there was Rs. 0.56 net profit for every one rupee investment in pea production.

\section{Costs and returns in cabbage cultivation (Rs/ha)}

Costs of cabbage production are presented in table 2 and the percentage share of various costs to the total cost (Cost C3) is also given in the table. The total cost of production i.e., cost C3 was found to be about Rs. 74008 per ha. The cost A1 which was the cost actually paid by the farmers was found to be Rs. 28035.79 per ha. The operational cost and material cost accounted for 35.97 per cent and 22.56 per cent of cost C3 and were estimated to be Rs. 26623.18 per ha and Rs. 16699.50 per ha, respectively. Intensive labour employment is renowned as peculiar to vegetable production and the contribution of human labour was recorded to be 32.55 per cent of cost C3. It was found to be Rs.
24086.95 per ha. Table 2 also revealed that rental value was the next most important item of cost with Rs. 16666.67 per ha i.e., 22.52 per cent of cost C3. Seed and expenditure on manure and fertilizers were the other important items of cost with Rs. 5634.78 per ha and Rs. 4673.32 per ha.

The returns over various costs of cabbage production are presented in table 2. The average cabbage yield was 169.71 quintals per hectare. The gross returns for cabbage production was found to be Rs. 92661.59 per ha where as the net returns over cost $\mathrm{C} 3$ was Rs. 18653.12 per ha. The ratio of gross returns to the total cost ( $\operatorname{cost} \mathrm{C} 3$ ) was found to be 1.25 in cabbage production indicating that there was a net profit of Rs. 0.25 for each one rupee investment.

\section{Costs and returns in tomato cultivation (Rs/ha)}

The perusal of table 3 revealed the costs of production of tomato. The total cost of production i.e., cost C3 was Rs. 125003.91 per ha. The operational cost accounted for about 41.04 per cent to the total cost (Cost C3) with expense of 51313.55. Cost incurred on input materials was observed to be Rs. 38589.77 per ha with 30.87 per cent of the total cost (Cost C3). The other costs, which include interest on working capital, rental value of land, depreciation and interest on fixed capital, were estimated at Rs. 23736.58 per ha sharing about 18.98 per cent of cost C3. A perusal of table further reveals that of total human labour cost, cost of family labour accounted for 35.42 per cent whereas hired labour contributed only 3.25 per cent of cost C3. Rental value of land and seed were the other important cost items.

Table 3 showed that per ha gross returns was estimated at Rs. 150562.71 per ha. The net returns over total cost (Cost C3) were 
amounting to Rs. 25558.79 per ha. It also revealed that the ratio of gross return to cost C3 was 1.20 indicating that there was a net profit of Rs. 0.20 for each one rupee investment.

\section{Costs and returns in bean cultivation}

Table 4 reveals that bean production was a profitable proposition in the study area. The component-wise various cost incurred in the production of bean is given in the table. A perusal of the table reveals that the cost incurred in labour was the highest amounting to Rs. 26949.80 per ha i.e., 25.99 per cent to the cost C3. The total material costs i.e., costs on seeds, fertilizers and manure, irrigation and plant protection chemicals were found to be Rs. 15793.72 per ha. The per hectare costs of cultivation was found to be about Rs. 103690. The other costs accounted for 22.17 per cent of the total cost (Cost C3).

Table.1 Costs and returns in pea cultivation (Rs/ha)

\begin{tabular}{|c|c|c|c|}
\hline $\begin{array}{l}\text { S.No } \\
\text { - }\end{array}$ & Particulars & Values & $\begin{array}{l}\text { Percentage to } \\
\text { Cost C3 }\end{array}$ \\
\hline A. & Operational cost & & \\
\hline 1. & Human labour & & \\
\hline a. & Hired labour & 3968.253968 & 5.506844565 \\
\hline \multirow[t]{2}{*}{ b. } & Family labour & 16712.01814 & 23.19168254 \\
\hline & Sub-total & 20680.27211 & 28.6985271 \\
\hline 2. & Bullock labour & & \\
\hline a. & Hired bullock labour & 1558.956916 & 2.163403222 \\
\hline \multirow[t]{3}{*}{ b. } & Owned bullock labour & 765.3061224 & 1.062034309 \\
\hline & Sub-total & 2324.263039 & 3.225437531 \\
\hline & Total & 23004.53515 & 31.92396463 \\
\hline B. & Material cost & & \\
\hline 1. & Seed & 9158.730159 & 12.70979726 \\
\hline 2. & Manure & 1853.741497 & 2.572483104 \\
\hline 3. & Fertilizers & 5187.188209 & 7.198389877 \\
\hline 4. & Plant protection & 2295.918367 & 3.186102927 \\
\hline \multirow[t]{2}{*}{5.} & Irrigation & 1200.80619 & 1.666388567 \\
\hline & Total & 19696.38442 & 27.33316173 \\
\hline $\mathrm{C}$. & Other costs & & \\
\hline 1. & Rental value of owned land & 16666.67 & 23.1287518 \\
\hline 2. & Depreciation on fixed assets & 2383.34 & 3.307420097 \\
\hline 3. & Interest on fixed assets & 2975.86 & 4.129674814 \\
\hline \multirow[t]{2}{*}{4.} & Interest on working capital & 782.6608088 & 1.086117838 \\
\hline & Total & 22808.53081 & 31.65196455 \\
\hline D. & Total cost of production at: & & \\
\hline 1. & Cost A1 & 29154.90224 & 40.45898176 \\
\hline 2. & Cost A2 & 29154.90224 & 40.45898176 \\
\hline 3. & Cost B1 & 32130.76224 & 44.58865657 \\
\hline 4. & Cost B2 & 48797.43224 & 67.71740837 \\
\hline
\end{tabular}




\begin{tabular}{|l|l|l|l|}
\hline 5. & Cost C1 & 48842.78038 & 67.78033911 \\
\hline 6. & Cost C2 & 65509.45038 & 90.90909091 \\
\hline 7. & Cost C2 & 65509.45038 & 90.90909091 \\
\hline 8. & Cost C3 & 72060.39542 & 100 \\
\hline E. & Yield (Qt1. / ha.) & 106.9727891 & \\
\hline F. & Selling price (Rs. /Qt1.) & 1053.717949 & \\
\hline G. & Gross returns & 112649.9433 & \\
\hline H. & Net returns over: & & \\
\hline 1. & Cost A1 & 83495.04107 & \\
\hline 2. & Cost A2 & 83495.04107 & \\
\hline 3. & Cost B1 & 80519.18107 & \\
\hline 4. & Cost B2 & 63852.51107 & \\
\hline 5. & Cost C1 & 63807.16293 & \\
\hline 6. & Cost C2 & 47140.49293 & \\
\hline 7. & Cost C2* & 47140.49293 & \\
\hline 8. & Cost C3 & 40589.54789 & \\
\hline & Net returns & 40589.54789 & \\
\hline & Returns per rupee invested & 1.563271235 & \\
\hline
\end{tabular}

Table.2 Costs and returns in cabbage cultivation (Rs/ha)

\begin{tabular}{|l|l|l|l|}
\hline S.No & Particulars & Values & $\begin{array}{l}\text { Percentage to } \\
\text { Cost C3 }\end{array}$ \\
\hline A. & Operational cost & & \\
\hline $\mathbf{1 .}$ & Human labour & & \\
\hline a. & Hired labour & 4898.55 & 6.61 \\
\hline b. & Family labour & 19188.40 & 25.93 \\
\hline & Sub-total & 24086.95 & 32.55 \\
\hline $\mathbf{2 .}$ & Bullock labour & & \\
\hline a. & Hired bullock labour & 1557.97 & 2.10 \\
\hline b. & Owned bullock labour & 978.26 & 1.32 \\
\hline & Sub-total & 2536.23 & 3.42 \\
\hline & Total & 26623.18 & 35.97 \\
\hline B. & Material cost & & \\
\hline 1. & Seed & 5634.78 & 7.61 \\
\hline 2. & Manure & 1521.73 & 2.05 \\
\hline 3. & Fertilizers & 3151.59 & 4.25 \\
\hline 4. & Plant protection & 3881.15 & 5.24 \\
\hline 5. & Irrigation & 2510.33 & 3.39 \\
\hline & Total & 16699.60 & 22.56 \\
\hline C. & Other costs & & \\
\hline 1. & Rental value of owned land & 16666.67 & 22.52 \\
\hline 2. & Depreciation on fixed assets & 2573.42 & 3.47 \\
\hline
\end{tabular}




\begin{tabular}{|l|l|l|l|}
\hline 3. & Interest on fixed assets & 3389.56 & 4.58 \\
\hline 4. & Interest on working capital & 1327.98 & 1.79 \\
\hline & Total & 23957.63 & 32.37 \\
\hline D. & Total cost of production at: & & \\
\hline 1. & Cost A1 & 28035.79 & 37.88 \\
\hline 2. & Cost A2 & 28035.79 & 37.88 \\
\hline 3. & Cost B1 & 31425.35 & 42.46 \\
\hline 4. & Cost B2 & 48092.02 & 64.98 \\
\hline 5. & Cost C1 & 50613.76 & 68.39 \\
\hline 6. & Cost C2 & 67280.43 & 90.91 \\
\hline 7. & Cost C2 & 67280.43 & 90.91 \\
\hline 8. & Cost C3 & 74008.47 & 100 \\
\hline E. & Yield (Qtl. / ha.) & 169.71 & \\
\hline F. & Selling price (Rs. /Qt1.) & 544.21 & \\
\hline G. & Gross returns & 92661.59 & \\
\hline H. & Net returns over: & & \\
\hline 1. & Cost A1 & 64625.79 & \\
\hline 2. & Cost A2 & 64625.79 & \\
\hline 3. & Cost B1 & 61236.23 & \\
\hline 4. & Cost B2 & 44569.56 & \\
\hline 5. & Cost C1 & 42047.83 & \\
\hline 6. & Cost C2 & 25381.16 & \\
\hline 7. & Cost C2* & 25381.16 & \\
\hline 8. & Cost C3 & 18653.12 & \\
\hline & Net returns & 18653.12 & \\
\hline & Returns per rupee invested & 1.25 & \\
\hline
\end{tabular}

Table.3 Costs and returns in tomato cultivation (Rs/ha)

\begin{tabular}{|l|l|l|l|}
\hline S.No. & Particulars & Values & $\begin{array}{l}\text { Percentage to } \\
\text { Cost C3 }\end{array}$ \\
\hline A. & Operational cost & & \\
\hline $\mathbf{1 .}$ & Human labour & & \\
\hline a. & Hired labour & 4067.79 & 3.25 \\
\hline b. & Family labour & 44279.66 & 35.42 \\
\hline & Sub-total & 48347.45 & 38.67 \\
\hline $\mathbf{2 .}$ & Bullock labour & & \\
\hline a. & Hired bullock labour & 1800.84 & 1.44 \\
\hline b. & Owned bullock labour & 1165.25 & 0.93 \\
\hline & Sub-total & 2966.10 & 2.37 \\
\hline & Total & 51313.55 & 41.05 \\
\hline B. & Material cost & & \\
\hline 1. & Seed & 15985.16 & 12.78 \\
\hline 2. & Manure & 1954.44 & 1.56 \\
\hline
\end{tabular}




\begin{tabular}{|c|c|c|c|}
\hline 3. & Fertilizers & 6805.08 & 5.44 \\
\hline 4. & Plant protection & 6334.74 & 5.06 \\
\hline \multirow[t]{2}{*}{5.} & Irrigation & 7510.33 & 6.00 \\
\hline & Total & 38589.77 & 30.87 \\
\hline C. & Other costs & & \\
\hline 1. & Rental value of owned land & 16666.67 & 13.33 \\
\hline 2. & Depreciation on fixed assets & 2469.23 & 1.97 \\
\hline 3. & Interest on fixed assets & 2952.65 & 2.36 \\
\hline \multirow[t]{2}{*}{4.} & Interest on working capital & 1648.03 & 1.31 \\
\hline & Total & 23736.58 & 18.98 \\
\hline D. & Total cost of production at: & & \\
\hline 1. & Cost A1 & 49740.94 & 39.79 \\
\hline 2. & Cost A2 & 49740.94 & 39.79 \\
\hline 3. & Cost B1 & 52693.59 & 42.15 \\
\hline 4. & Cost B2 & 69360.26 & 55.48 \\
\hline 5. & Cost $\mathrm{C} 1$ & 96973.25 & 77.57 \\
\hline 6. & Cost $\mathrm{C} 2$ & 113639.92 & 90.90 \\
\hline 7. & Cost C2* & 113639.92 & 90.90 \\
\hline 8. & Cost $\mathrm{C} 3$ & 125003.91 & 100 \\
\hline E. & Yield (Qtl. / ha.) & 155.50 & \\
\hline F. & Selling price (Rs. /Qt1.) & 981.50 & \\
\hline G. & Gross returns & 150562.71 & \\
\hline $\mathrm{H}$. & Net returns over: & & \\
\hline 1. & Cost A1 & 100821.76 & \\
\hline 2. & Cost A2 & 100821.76 & \\
\hline 3. & Cost B1 & 97869.11 & \\
\hline 4. & Cost B2 & 81202.44 & \\
\hline 5. & Cost $\mathrm{C} 1$ & 53589.45 & \\
\hline 6. & Cost $\mathrm{C} 2$ & 36922.78 & \\
\hline 7. & Cost $\mathrm{C} 2 *$ & 36922.78 & \\
\hline \multirow[t]{3}{*}{8.} & Cost C3 & 25558.79 & \\
\hline & Net returns & 25558.79 & \\
\hline & Returns per rupee invested & 1.20 & \\
\hline
\end{tabular}

Table.4 Costs and returns in bean cultivation (Rs/ha)

\begin{tabular}{|l|l|l|l|}
\hline S.No. & Particulars & Values & $\begin{array}{l}\text { Percentage to } \\
\text { Cost C3 }\end{array}$ \\
\hline A. & Operational cost & & \\
\hline $\mathbf{1 .}$ & Human labour & & \\
\hline a. & Hired labour & 4131.27 & 3.98 \\
\hline b. & Family labour & 22818.53 & 22.00 \\
\hline & Sub-total & 26949.80 & 25.99 \\
\hline $\mathbf{2 .}$ & Bullock labour & & \\
\hline
\end{tabular}




\begin{tabular}{|c|c|c|c|}
\hline a. & Hired bullock labour & 1061.77 & 1.02 \\
\hline \multirow[t]{3}{*}{ b. } & Owned bullock labour & 1351.35 & 1.30 \\
\hline & Sub-total & 2413.12 & 2.32 \\
\hline & Total & 29362.93 & 28.31 \\
\hline B. & Material cost & & \\
\hline 1. & Seed & 7374.51 & 7.11 \\
\hline 2. & Manure & 1795.36 & 1.73 \\
\hline 3. & Fertilizers & 2549.80 & 2.45 \\
\hline 4. & Plant protection & 2557.91 & 2.46 \\
\hline \multirow[t]{2}{*}{5.} & Irrigation & 1516.12 & 1.46 \\
\hline & Total & 15793.72 & 15.23 \\
\hline C. & Other costs & & \\
\hline 1. & Rental value of owned land & 16666.67 & 16.07 \\
\hline 2. & Depreciation on fixed assets & 2436.87 & 2.35 \\
\hline 3. & Interest on fixed assets & 3054.80 & 2.94 \\
\hline \multirow[t]{2}{*}{4.} & Interest on working capital & 836.29 & 0.80 \\
\hline & Total & 22994.63 & 22.17 \\
\hline D. & Total cost of production at: & & \\
\hline 1. & Cost A1 & 51724.80 & 49.88 \\
\hline 2. & Cost A2 & 51724.80 & 49.88 \\
\hline 3. & Cost B1 & 54779.60 & 52.82 \\
\hline 4. & Cost B2 & 71446.27 & 68.90 \\
\hline 5. & Cost $\mathrm{C} 1$ & 77598.13 & 74.83 \\
\hline 6. & Cost $\mathrm{C} 2$ & 94264.80 & 90.90 \\
\hline 7. & Cost C2* & 94264.80 & 90.90 \\
\hline 8. & Cost $\mathrm{C} 3$ & 103691.28 & 100 \\
\hline E. & Yield (Qtl. / ha.) & 99.51 & \\
\hline F. & Selling price (Rs. /Qtl.) & 1177.22 & \\
\hline G. & Gross returns & 114464.38 & \\
\hline H. & Net returns over: & & \\
\hline 1. & Cost A1 & 62739.57 & \\
\hline 2. & Cost A2 & 62739.57 & \\
\hline 3. & Cost B1 & 59684.77 & \\
\hline 4. & Cost B2 & 43018.10 & \\
\hline 5. & Cost $\mathrm{C} 1$ & 36866.24 & \\
\hline 6. & Cost $\mathrm{C} 2$ & 20199.57 & \\
\hline 7. & Cost $\mathrm{C} 2 *$ & 20199.57 & \\
\hline \multirow[t]{3}{*}{8.} & Cost C3 & 10773.09 & \\
\hline & Net returns & 10773.09 & \\
\hline & Returns per rupee invested & 1.10 & \\
\hline
\end{tabular}

A perusal of the table 4 further reveals that human labour (family and hired), rental value and seed were the important items of cost in the area.
The gross returns were Rs. 114464.38 per hectare giving a net return of Rs. 10773.09 per hectare. The ratio of gross returns to the 
cost C3 was calculated as 1.10 indicating that there was Rs. 0.10 net profit for every one rupee investment in bean production.

In conclusion, sectors like horticulture (both fruit and vegetable cultivation) have a comparative advantage in the region due to its agro-climatic conditions. The analysis of profitability of 4 major vegetables grown in Nainital district showed that it is advantageous to adopt vegetable production. The returns per rupee invested from pea, cabbage, tomato, and bean were 1.56, 1.25, 1.20 and 1.10 respectively. Thus, it is highly recommended to farmers to grow vegetables in hilly region like Uttarakhand.

\section{References}

Bala, B., Sharma, N. and Sharma, R.K. 2011. Cost and return structure for the promising enterprise of off-season vegetables in Himachal Pradesh, Argil. Eco. Res. Review, 24(1): 141-142.

Botha, J. Witkowski, E.T.F. and Shackleton, C.M. 2004. Market profiles and trade in the lowveld, South Africa. Environ. Conservation, 31(1): 38-46.

Indian Horticulture Database. 2016. National Horticulture Board, Department of
Agriculture and Cooperation, Govt. of India.

Kareemulla, K., Tewari, R.K., Singh, B. and Kumar, K. 2007. Production and marketing of Indian gooseberry-aonla (Emblica officinalis) in Pratapgarh district of Uttar Pradesh. Indian J. Agri. Marketing, 21(2): 41.

Kaur, A., Sethi, K. and Karan, S.K. 2006. Marketing pattern of green peas in Punjab. Indian J. Agri. Marketing, 20(2): 118-123.

Kumar, A. and Arora, V.P.S. 2003. An analysis of marketed surplus and marketing cost of vegetables in Uttaranchal, Indian J. Agri. Marketing, 17(1): 63-74.

Randev, A.K. 2005. Marketing of Apple in Shimla district of Himachal PradeshIndia, Indian J. Agri. Marketing, 19(3): 13-16.

Sharma, N., Gupta, A. and Arora, R.K. 2011. Constraints for Vegetable Production in the Hilly Regions of Jammu Division, $J$. Hill Agri., 2(1): 38-41.

Thakur, D.S., Lal, H., Saini, A.S. 1997. Market supply response and marketing problems of farmers in the hills, Indian J. Agri. Eco., 52(1): 139-150.

\section{How to cite this article:}

Harshika Choudhary, Deepshikha Bisht, P.S. Badal, Virendra Singh, Ritu Shah and Manohar Saryam. 2017. Profitability of Vegetables in Hill Agriculture: An Economic Analysis. Int.J.Curr.Microbiol.App.Sci. 6(8): 1674-1682. doi: https://doi.org/10.20546/ijcmas.2017.608.201 